\title{
Reducing Simulation Performance Gap from Hempcrete Buildings Using Multi Objective Optimization
}

\author{
Ataitiya Bana, Ljubomir Jankovic \\ Zero Carbon Lab, School of Creative Arts, University of Hertfordshire, Hatfield, UK.
}

\begin{abstract}
Hempcrete is increasingly used as a construction material, as it provides stable temperature and relative humidity conditions in buildings. In addition to low energy operations, buildings built from hempcrete possess negative embodied $\mathrm{CO}_{2}$, absorbed into the hemp plant material. Hempcrete is hard to represent in design simulations because standard dynamic simulation tools do not have a built-in capability to simulate its effect accurately, due to the specific material structure and combined heat and moisture transfer, causing a considerable performance gap. This paper investigates appropriate specification of key parameters to be used in simulation of hempcrete, to reduce simulation performance gap from hempcrete buildings, using multi objective optimisation, to facilitate hempcrete simulation.
\end{abstract}

\section{Introduction}

Hempcrete as a construction material contributes to the resilience of buildings and mitigates the effects of climate change in the built environment as it possesses negative embodied $\mathrm{CO}_{2}$, absorbed into the hemp plant material while improving the thermal performance of buildings and increasing the quality of living for the inhabitants of the buildings, by providing a clean breathable environment, with stable internal environmental conditions. It provides stable internal temperatures and relative humidity, characterised with low diffusivity and high thermal inertia in buildings. It warms up easily in a short time and once heated, it slowly releases the heat to its surrounding when the temperature drops (Evrard, 2008). Hempcrete is an example of a vapour permeable and "breathable" building material that utilizes a combination of thermal and hygroscopic attributes to enable good thermal performance. However, it performs more efficiently in real life operation of the building than when it is simulated for design and construction, making it hard to represent in design simulations due to its specific material structure with combined heat and moisture transfer, causing a 'performance gap'. The performance gap is a discrepancy between the performance of the simulation model and the actual building, a degree of inaccuracy which is contained in a simulation model when it is first built (Monfet et al., 2009). Advanced application and simulation of hempcrete is hindered by the absence of accurate design tools, because standard dynamic simulation software, such as Design Builder, IES Virtual
Environment, EnergyPlus and other tools do not have a built-in capability to accurately simulate the effect of this material due to its specific structure, causing a performance gap.

This paper is aimed at investigating how to reduce simulation performance gap in a hempcrete building, using multi objective optimization. Multi-objective optimization is a method which focuses on design objective functions to provide design parameters that achieve certain performance criteria (Sariyildiz, Bittermann and Ciftcioglu, 2015). These will involve modelling both heat and moisture transfer and comparing simulation outputs with monitoring data to minimise error between them. Through variation of significant parameters, parametric simulations, and multi-objective optimisation are used to investigate and identify appropriate specification of materials in the simulation tools. Integrating thermal simulations with optimization aims to identify the most favourable variants of the parameters on the basis of potentially contrasting needs.

\section{Methodology}

\section{Experimental Research}

Several simulation experiments will be carried out, and the best simulation output from the experiments will be investigated through multi objective optimization in jEPlus+EA, towards reducing simulation performance gap. Kicinger and Wiegand (2009) stated that an experimental research follows a specific plan or procedure and also requires collection and interpretation of data. This paper involves data collection, simulation experiments, interpretation of experiment results, multi objective optimization and presenting of final results with a clear articulation of experimental steps. The experimental simulations will be carried out using IES Virtual environment, and the simulations for heat and moisture transfer will be carried out in EnergyPlus, to be coupled in jEPlus+EA for optimization. IES Virtual Environment is an excellent standard dynamic simulation software, which has the capacity to run thermal simulations and also create a complete 3D model of the building geometry for simulation. But it doesn't have the capability to run combined heat and moisture transfer simulations of a whole building through walls and building envelope. Whereas, EnergyPlus possess capabilities for advanced building simulations such as, combined heat and moisture transfer, conduction transfer functions, advanced fenestration models, and many other 
notable features (Energyplus.net). However, it does not have the capability to create model of a building geometry on its own. In 2008 EnergyPlus was reformed with features to enable its integration with other software's such as Open Studio and Design Builder as a plug-in for 3D software's as applicable, to help transport modelled building geometry into EnergyPlus, as an IDF file for energy simulation purposes. EnergyPlus is a consolebased program that reads input and writes output to text files. It enables a number of utilities including input data file (IDF) editor. An input data file (IDF) is a format for text files containing the data, describing the building and / or HVAC system to be simulated, for creating input files using a spreadsheet-like interface (Energyplus.net). Given the objectives of this study, there is a need to create a model of the 3D geometry of the test cell to enable a visual and straightforward method of assigning the specific building material to the appropriate building element of the test cell model, for simulations. Hence, both software's will be used at various stages to run simulations as required, for analysing the data. This is why, the building geometry of the test cell was created first in IES Virtual Environment and simulations were run in passive unregulated free - floating mode for experiments, and the model was transported into EnergyPlus in IDF for combined heat and moisture transfer simulation.

Multi objective optimization using jEPlus+EA carried out in this paper, focuses on design objectives function to provide results, as a constructive means to appropriate design parameters for hempcrete building design. jEPlus+EA optimization, uses the non-dominated sorting genetic algorithm (NSGA II) in the background as an evolutionary process (Deb et al. 2002), and proposes the posteriori preference method to identify and investigate the most energy efficient and favourable design parameter from the simulation experiments, which will create a hempcrete construction system to reduce simulation performance gap. In the posteriori preference method, no preferences of the designer are considered. After the Pareto set has been generated, the designer chooses a favourable solution from the set of solution alternatives as the optimum solution (Augusto, Fouad and Caro, 2012).

\section{Data Collection}

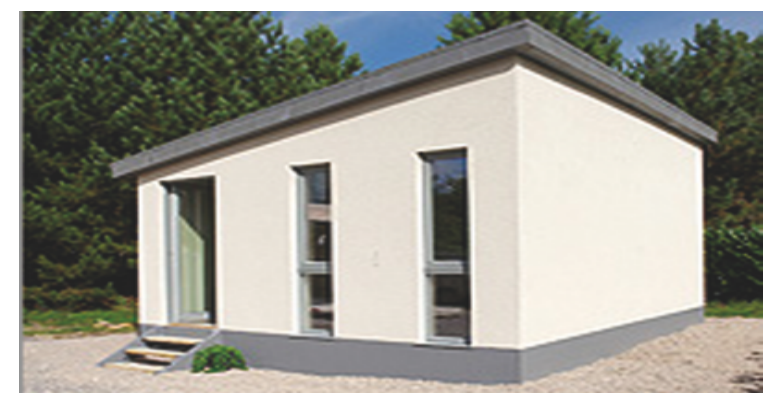

Figure 1: Hempod.

The obtained data is of a hempcrete test cell building called 'Hempod', which was located in Bath, UK. The dimensions of Hempod are $5.2 \mathrm{~m}$ by $4.0 \mathrm{~m}$ and its $2.7 \mathrm{~m}$ high headroom, with a mono-pitched roof. It contains a north-facing window $1.1 \mathrm{~m}$ wide and $1.3 \mathrm{~m}$ high, a south- facing door $0.9 \mathrm{~m}$ wide and two south facing windows $0.6 \mathrm{~m}$ wide and $2.25 \mathrm{~m}$ high as seen from the image in Figure 1 above. The collected data was obtained from monitoring internal air temperature, relative humidity and other variables on hourly intervals for a period of three weeks.

\section{Modelling of Hempod}

The collected dimensions of hempod's monitored data was inputted into IES Virtual Environment to be modelled for simulation. And the first simulation was carried out while the model was in passive unregulated free-floating mode, so that no heating or cooling was specified in the model. Figure 2 below, shows the 3D geometry model of hempod in IES Virtual Environment (Iesve.com, 2011).

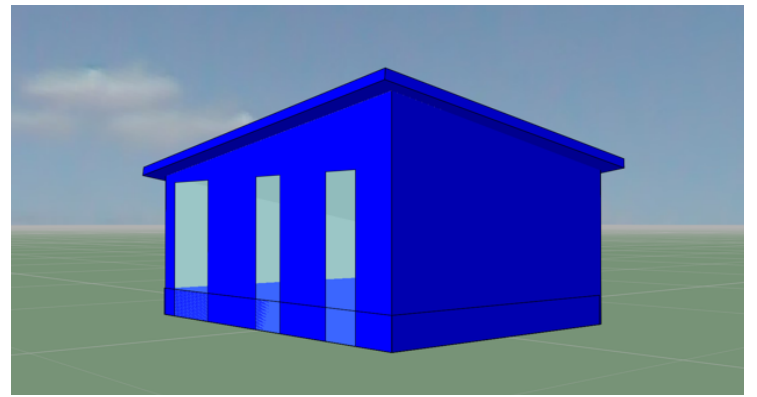

Figure 2: Hempod 3D Geometry.

The collected monitoring data was entered into Microsoft excel to analyse performance gap by confirming the actual value of temperature and relative humidity, before simulation experiments were performed. Figures 3 and 4 below, show the actual/monitored temperature and relative humidity values for hempod respectively.

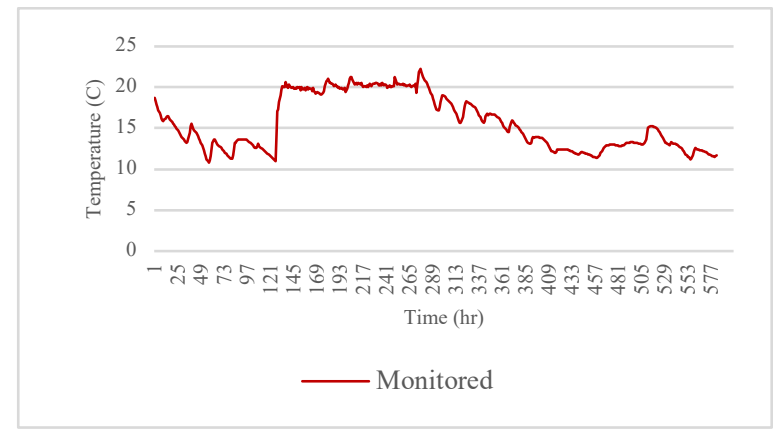

Figure 3: Monitored Hempod temperature data.

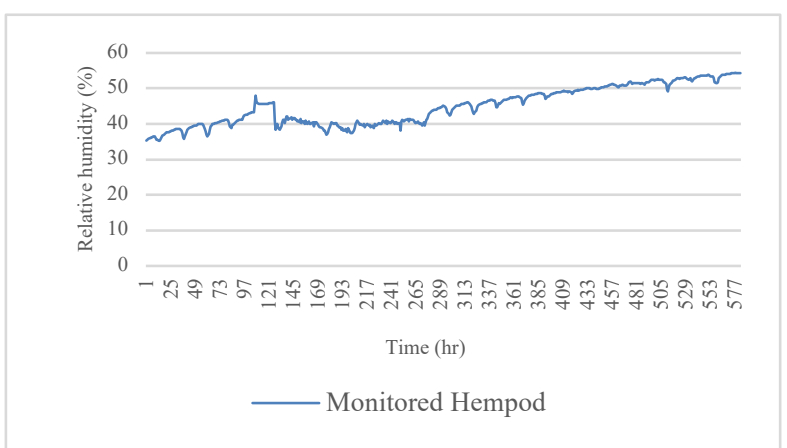

Figure 4: Monitored Hempod relative humidity data. 
The wall construction detail of Hempod is as shown in Table 1 below.

Table 1: Hempod wall construction.

\begin{tabular}{|c|c|c|c|c|c|}
\hline & 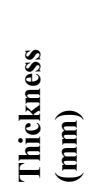 & 总 & 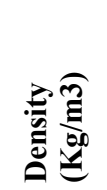 & 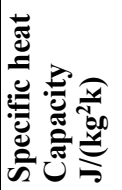 & 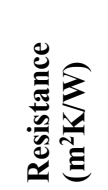 \\
\hline $\begin{array}{l}\text { External } \\
\text { Rendering }\end{array}$ & 9.0 & 0.5000 & 1300.0 & 1000.0 & 0.0180 \\
\hline Hempcrete & 200.0 & 0.0500 & 275.0 & 1750.0 & 4.0000 \\
\hline $\begin{array}{l}\text { Gypsum } \\
\text { Plastering }\end{array}$ & 12.5 & 0.4200 & 1200.0 & 837.0 & 0.0214 \\
\hline
\end{tabular}

Simulated results were obtained and transferred into Microsoft Excel spreadsheet, to calculate the root mean square error (RMSE).

\section{Experimental Simulation in IES Virtual Environment}

For the experimental simulations, different construction components were applied to the hempod model for experimentation in IES Virtual Environment software. The construction component of hempod walls was adjusted severally and simulation was run consecutively to observe the variations in simulation outputs, and how the construction changes in the wall could affect the performance gap positively by reducing it. Below are the details of the simulation experiments.

'Hem' is the name given to the first experimental model of hempod. All the changes applied in Hempod for creating Hem were in the wall construction, where hempcrete was used as the construction material. The wall was cut in slices of $50 \mathrm{~mm}$ thickness; as seen from figure 5 below, there were a total of five layers of hempcrete making the overall wall thickness $268 \mathrm{~mm}$ including $9 \mathrm{~mm}$ external rendering and $9 \mathrm{~mm}$ internal gypsum plastering. The five layers of hempcrete used in this experiment is different from the solid $250 \mathrm{~mm}$ thick hempcrete because unlike in conventional brick and block construction, the co-heating test in a hempcrete house exhibited unexpected behaviour. Instead of heating on to a considerable period, it was stopped by a thermostat in half an hour and coincidentally, half an hour later, it started again. This suggests that hempcrete may have a configuration equivalent to a series of slices of high-density material and insulation material. This was the reason for experimenting with slices in this research. Simulation was run in passive unregulated freefloating mode, and the resultant temperature and relative humidity were collected and post-processed in a spreadsheet.

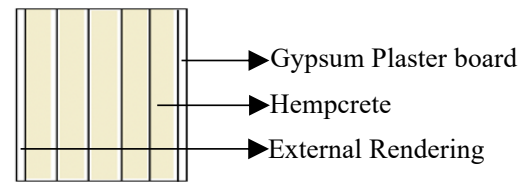

Figure 5: Hem Wall Construction.
'Hem C' is the second experimental model of Hempod. The wall construction was changed to layers of hempcrete and cast concrete with $75 \mathrm{~mm}$ thickness. As seen from Figure 6 below, hempcrete was placed in layers alternating with cast concrete, and hempcrete was the last layer before the external rendering and cast concrete the last layer before the internal gypsum plastering. The total wall thickness was $318 \mathrm{~mm}$, including two layers of $75 \mathrm{~mm}$ thick hempcrete, two layers of $75 \mathrm{~mm}$ thick cast concrete, $9 \mathrm{~mm}$ thick external rendering and $9 \mathrm{~mm}$ thick internal gypsum plastering. Simulation was run in passive unregulated free-floating mode; the resultant temperature and relative humidity were collected for post processing in a spreadsheet.

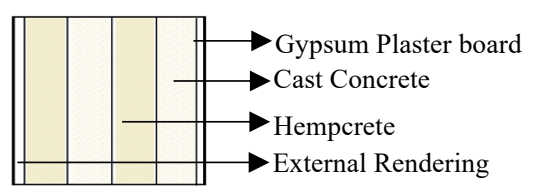

Figure 6: Hem C Wall Construction

'Hemm' is the third experimental model of Hempod. The wall was cut in slices of $75 \mathrm{~mm}$ hempcrete; as seen from Figure 7 below, there were a total of four layers of hempcrete making the overall wall thickness $318 \mathrm{~mm}$ including $9 \mathrm{~mm}$ thick external render and $9 \mathrm{~mm}$ thick internal gypsum plastering. Simulation was run in passive unregulated free-floating mode and the resultant temperature and relative humidity were collected for postprocessing in a spreadsheet.

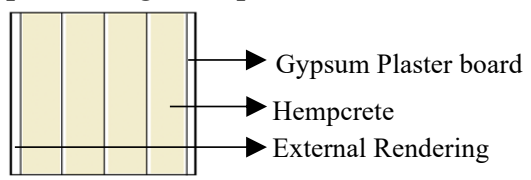

Figure 7: Hemm Wall Construction.

'Hemp C' is the fourth experimental model of Hempod. The layers of hempcrete and cast concrete were still $75 \mathrm{~mm}$ thick but the alternating placement was changed with cast concrete being the outside layer before external rendering. As seen from Figure 8 below, there was a total wall thickness of $318 \mathrm{~mm}$, two layers of $75 \mathrm{~mm}$ thick hempcrete, two layers of $75 \mathrm{~mm}$ cast concrete, $9 \mathrm{~mm}$ external rendering and $9 \mathrm{~mm}$ internal gypsum plastering. Simulation was run in passive unregulated free-floating mode and the resultant temperature and relative humidity were collected and transferred into spreadsheet for postprocessing.

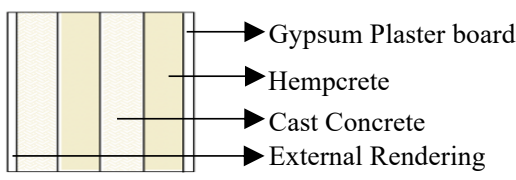

Figure 8:Hemp C Wall Construction.

'Hpod' is the fifth experimental model of Hempod. In the Hpod wall construction, the layers of hempcrete and cast concrete was $50 \mathrm{~mm}$ thick and the wall construction layers were placed in such a way that cast concrete is the outer layer before external rendering, and also cast concrete was the last inner layer before the internal gypsum plaster board. As seen from Figure 9 below, 
there was a total of two $50 \mathrm{~mm}$ thick hempcrete wall layers and three cast concrete layers, making the overall wall thickness $268 \mathrm{~mm}$ including $9 \mathrm{~mm}$ external rendering and $9 \mathrm{~mm}$ internal gypsum plastering. Simulation was run in passive unregulated free-floating mode. The resultant temperature and relative humidity were collected for post processing in a spreadsheet.

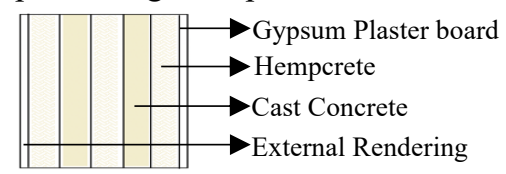

Figure 9: Hpod wall construction.

Figures 10 and 11 below, show the collated resultant temperature and relative humidity of hempod experimental models (Hem, Hem C, Hemm, Hemp C and Hpod) after the simulation.

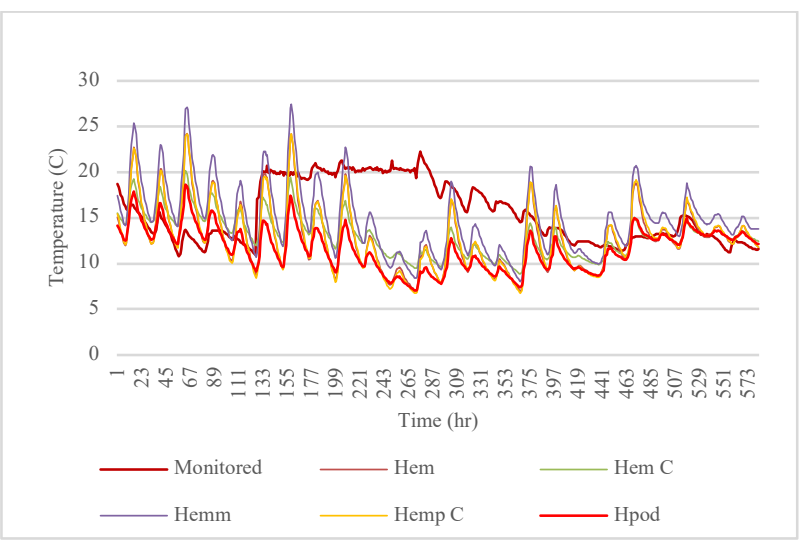

Figure 10:Experimental simulation of hempod temperature values.

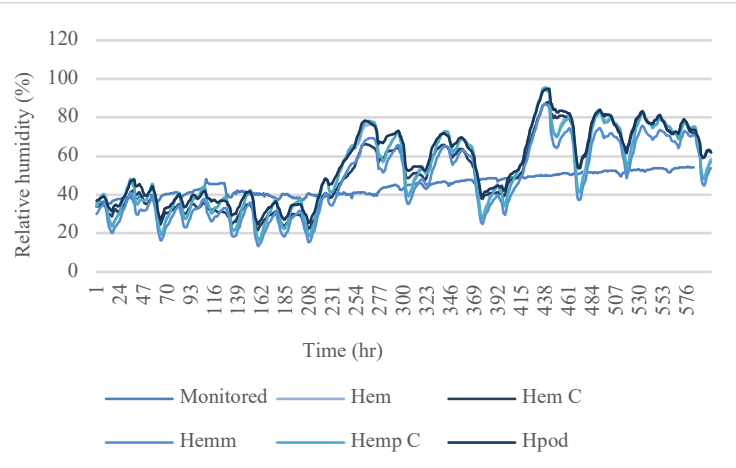

Figure 11:Experimental simulation of hempod relative humidity values.

\section{Root Mean Square Error calculation (RMSE)}

Root Mean Square Error (RMSE) measures how much error there is between two data sets, a lower value generally indicates a better performance of the simulation model (Cooke, 2018). Specifically, in this paper, it will be used for post processing the outputs from experimental simulation, to compare an actual or monitored value with a predicted or simulated value. Calculating the error between monitoring and simulation results is paramount, as it is the initial crucial step towards reducing simulation performance gap. The outputs of experimental simulation (Hem, Hem C, Hemm, Hemp C and Hpod) of hempod were transferred into Microsoft excel spreadsheet with the monitored measured values of Hempod to calculate the root mean square error.

Table 2:Root mean square error (Temperature).

\begin{tabular}{|c|c|c|c|c|c|}
\hline Hempod & Hem & HemC & Hemm & HempC & Hpod \\
\hline $\begin{array}{c}\text { RMSE } \\
\left({ }^{\circ} \mathrm{C}\right)\end{array}$ & 5.6 & 4.7 & 5.0 & 5.7 & 6.0 \\
\hline
\end{tabular}

Table 3:Root mean square error (Relative humidity).

\begin{tabular}{|c|c|c|c|c|c|}
\hline Hempod & Hem & HemC & Hemm & HempC & Hpod \\
\hline $\begin{array}{c}\text { RMSE } \\
(\%)\end{array}$ & 18.0 & 16.3 & 15.4 & 18.1 & 18.5 \\
\hline
\end{tabular}

As seen above from Tables 2 and 3, Hemm construction considerably has the lowest RMSE value, with temperature $5.0^{\circ} \mathrm{C}$ and Relative humidity $15.4 \%$ meaning that it is the construction detail to be focused on and further investigated through heat and moisture transfer simulations and multi objective optimization, for reducing simulation performance gap.

\section{EnergyPlus Heat and Moisture Transfer Simulation}

The combined heat and moisture transfer (HAMT) in EnergyPlus, are a solution algorithm which is a finite element. And the model simulates the movement and storage of heat and moisture in surfaces simultaneously from and to both the internal and external environments (Energyplus.net, 2016). The HAMT model descriptions are dependent on some factors of the material such as the moisture content, porosity, moisture dependent thermal conductivity, moisture transfer, and convective vapour transfer. For the purpose of this study, temperature and relative humidity values are the only parameters that will be considered for HAMT model in EnergyPlus. Given that Hempod (Hemm) is the wall construction with the lowest RMSE from the simulation experiments carried out, its construction compositions were entered into EnergyPlus for combined heat and moisture transfer simulations. This is to demonstrate the movement of heat and moisture through the Hempod (Hemm) wall construction. EnergyPlus has the capacity to provide temperature and moisture profiles through any composite walls to demonstrate heat and moisture transfer, as well as identify surfaces with high surface humidity. In this study, due to hempcrete's specific material structure and combined heat and moisture transfer, causing a considerable performance gap, the HAMT simulation performed, is to develop the model in idf file as a significant parameter for multi-objective optimisation. The idf file is coupled into jEPlus to form the parameters for the optimization, used to investigate and identify appropriate specification of materials in the simulation tools.

In EnergyPlus, surfaces are made up of layers of materials. And each surface is split into its constituent materials, which is further split up into cells through depth. The heat and moisture transfer model will generate at most ten (10) cells per material, and its where most 
changes are expected, and necessary detail is needed. The heat and moisture transfer simulation performed, generated five (5) cells per surface of material through the depth of the Hemm wall, making a total of 30 cells through Hempod (Hemm) wall. The simulation outputs of temperature and relative humidity movement through the walls from the heat and moisture transfer simulation conducted are as seen below. Figure 12 and figure 13 below, show the temperature profile as movement of heat and relative humidity profile as movement of moisture respectively. The profiles were selected from the set of outputs generated from the simulations. And the figure 12 and 13, is the heat and moisture transfer for one hour out of the 24 hours of/by 3 weeks the simulation was run for.

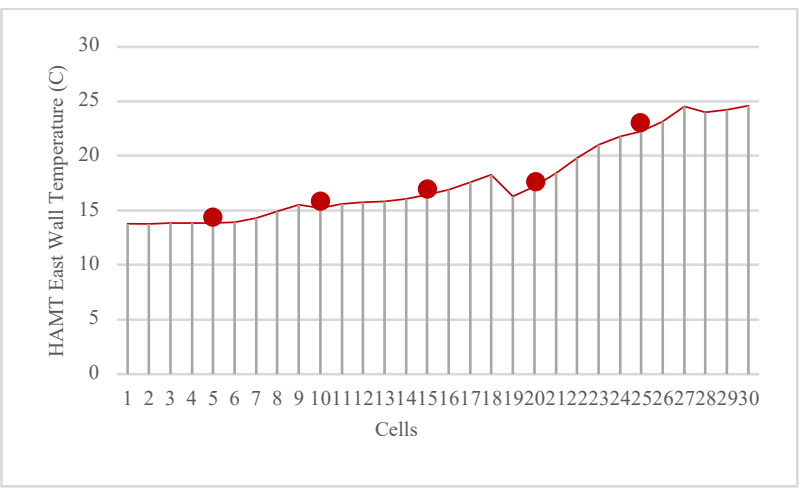

Figure 12: HAMT Temperature.

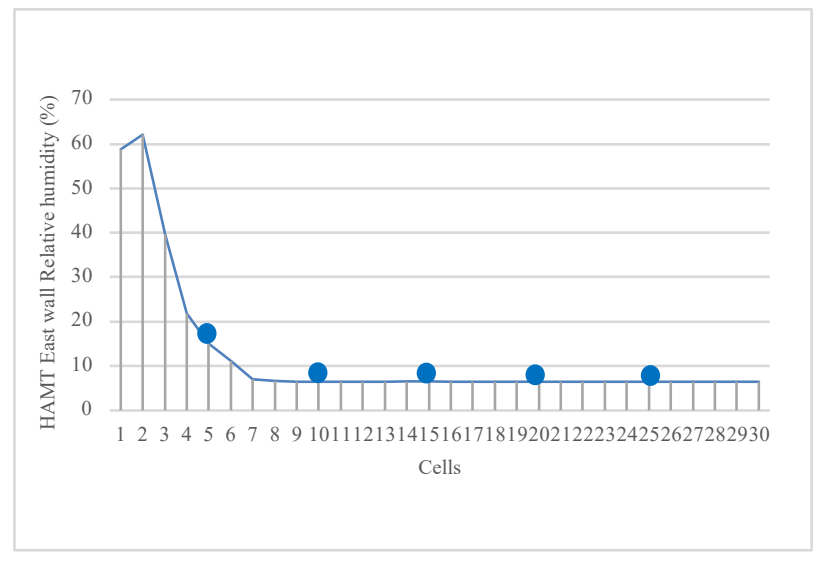

Figure 13: HAMT Relative humidity.

After the HAMT simulations of Hempod (Hemm) was conducted, Figure 14 and 15 below, show the room air temperature and relative humidity of the Hempod respectively.

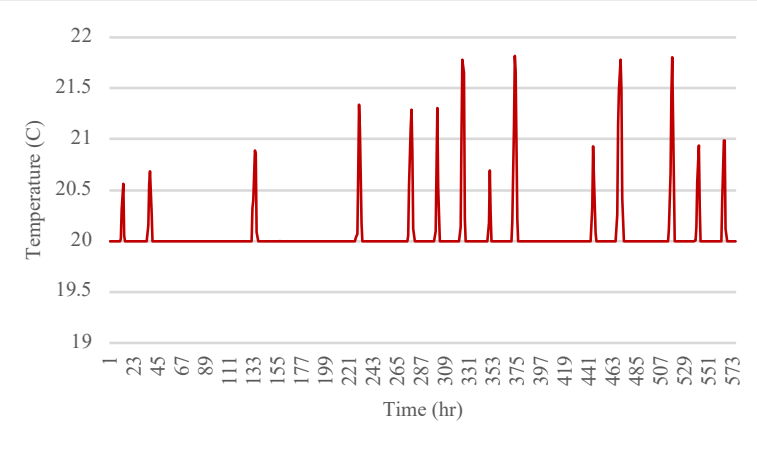

Figure 14:Temperature values of Hemm HAMT simulation.

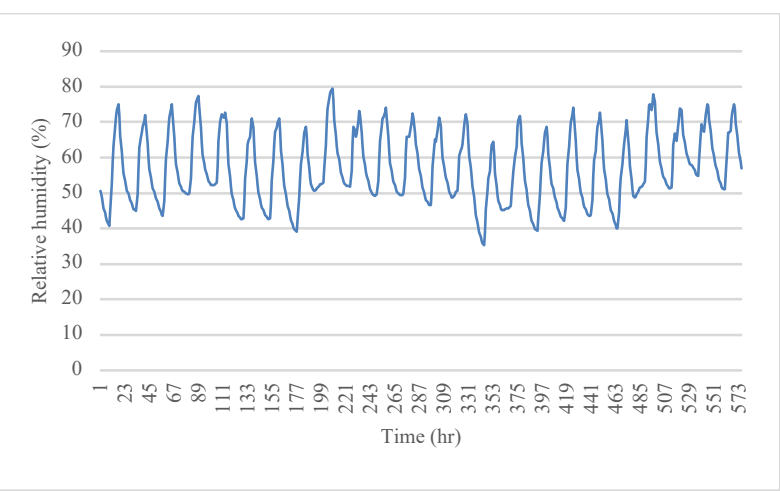

Figure 15: Relative humidity values of Hemm HAMT simulation.

Table 4: Hemm wall construction properties.

\begin{tabular}{|c|c|c|c|c|c|}
\hline 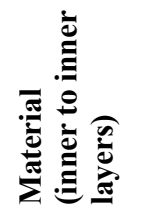 & 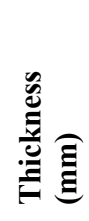 & 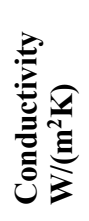 & 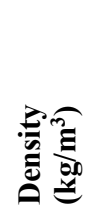 & 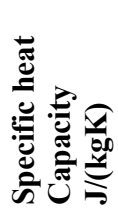 & 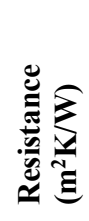 \\
\hline $\begin{array}{l}\text { Gypsum } \\
\text { Plastering }\end{array}$ & 12.5 & $\begin{array}{c}0.420 \\
0\end{array}$ & $\begin{array}{c}1200 . \\
0\end{array}$ & 837.0 & $\begin{array}{c}0.021 \\
4\end{array}$ \\
\hline $\begin{array}{l}\text { Hempcret } \\
\mathrm{e}\end{array}$ & 0.75 & 0.05 & 275.0 & $\begin{array}{c}1750 . \\
0\end{array}$ & $\begin{array}{c}4.000 \\
0\end{array}$ \\
\hline $\begin{array}{l}\text { Hempcret } \\
\mathrm{e}\end{array}$ & 0.75 & 0.05 & 275.0 & $\begin{array}{c}1750 . \\
0\end{array}$ & $\begin{array}{c}4.000 \\
0\end{array}$ \\
\hline $\begin{array}{l}\text { Hempcret } \\
\mathrm{e}\end{array}$ & 0.75 & 0.05 & 275.0 & $\begin{array}{c}1750 . \\
0\end{array}$ & $\begin{array}{c}4.000 \\
0\end{array}$ \\
\hline $\begin{array}{l}\text { Hempcret } \\
\mathrm{e}\end{array}$ & 0.75 & 0.05 & 275.0 & $\begin{array}{c}1750 . \\
0\end{array}$ & $\begin{array}{c}4.000 \\
0\end{array}$ \\
\hline $\begin{array}{l}\text { External } \\
\text { Renderin } \\
\mathrm{g}\end{array}$ & 9.0 & $\begin{array}{c}0.500 \\
0\end{array}$ & $\begin{array}{c}1300 . \\
0\end{array}$ & $\begin{array}{c}1000 . \\
0\end{array}$ & $\begin{array}{c}0.018 \\
0\end{array}$ \\
\hline
\end{tabular}

As seen from figure 14 and 15 above, there was an average room air temperature of $20.85^{\circ} \mathrm{C}$, with maximum temperature value as $21.7^{\circ} \mathrm{C}$ and minimum temperature 
value of $20^{\circ} \mathrm{C}$. For relative humidity, there was an average relative humidity of $58.75 \%$, and maximum value was $79.8 \%$ with the minimum relative humidity value as $37.7 \%$. A table containing the material properties of Hempod (Hemm) wall construction is as seen in Table 4 below.

Table 5: Hemm roof construction properties.

\begin{tabular}{|c|c|c|c|c|c|}
\hline 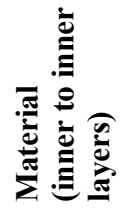 & 跑 & 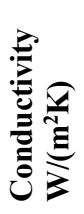 & 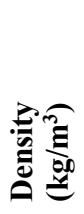 & 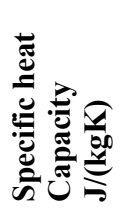 & 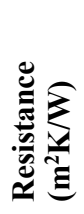 \\
\hline $\begin{array}{l}\text { Ceiling } \\
\text { board }\end{array}$ & 9.0 & $\begin{array}{c}0.210 \\
0\end{array}$ & 700 & $\begin{array}{c}1000 . \\
0\end{array}$ & $\begin{array}{c}0.059 \\
5\end{array}$ \\
\hline Cavity & 50 & & & & \\
\hline $\begin{array}{l}\text { Concrete } \\
\text { deck }\end{array}$ & 100 & 2.000 & $\begin{array}{c}2400 . \\
0\end{array}$ & $\begin{array}{c}1000 . \\
0\end{array}$ & $\begin{array}{c}0.050 \\
0\end{array}$ \\
\hline $\begin{array}{l}\text { Felt } \\
\text { Bitumen } \\
\text { layer }\end{array}$ & 0.1 & $\begin{array}{c}0.500 \\
0\end{array}$ & 1700 & $\begin{array}{c}1000 . \\
0\end{array}$ & $\begin{array}{c}0.000 \\
2\end{array}$ \\
\hline $\begin{array}{l}\text { Roof } \\
\text { covering }\end{array}$ & 0.20 & $\begin{array}{c}0.500 \\
0\end{array}$ & 1300 & $\begin{array}{c}1000 . \\
0\end{array}$ & $\begin{array}{c}0.018 \\
0\end{array}$ \\
\hline $\begin{array}{l}\text { Insulatio } \\
\mathrm{n}\end{array}$ & $\begin{array}{c}150 . \\
0\end{array}$ & $\begin{array}{c}0.030 \\
0\end{array}$ & 40.0 & 1450 & $\begin{array}{c}5.146 \\
7\end{array}$ \\
\hline
\end{tabular}

Table 6: Hemm floor construction properties.

\begin{tabular}{|c|c|c|c|c|c|}
\hline 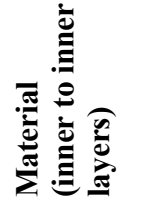 & 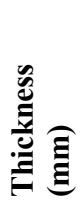 & 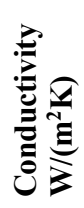 & 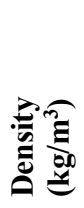 & 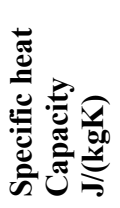 & 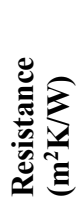 \\
\hline $\begin{array}{l}\text { Chipboar } \\
\text { d floor }\end{array}$ & 20.0 & 0.13 & 500.0 & $\begin{array}{c}1600 . \\
0\end{array}$ & $\begin{array}{c}0.153 \\
8\end{array}$ \\
\hline Cavity & 50 & & & & \\
\hline Insulation & $\begin{array}{c}150 . \\
0\end{array}$ & $\begin{array}{c}0.02 \\
5\end{array}$ & 700.0 & $\begin{array}{c}1000 . \\
0\end{array}$ & $\begin{array}{c}4.000 \\
0\end{array}$ \\
\hline $\begin{array}{l}\text { Cast } \\
\text { concrete }\end{array}$ & 100 & $\begin{array}{c}2.30 \\
0\end{array}$ & $\begin{array}{c}2300 . \\
0\end{array}$ & $\begin{array}{c}1000 . \\
0\end{array}$ & $\begin{array}{c}0.032 \\
6\end{array}$ \\
\hline
\end{tabular}

\section{Optimization using jEPlus + EA}

Multi objective Optimization was carried out to identify the optimum solution from the hempod (Hemm) simulations. The optimization objectives were to minimize RMSE from temperature (v1) and relative humidity (v2). The input data file (idf) of EnergyPlus heat and moisture transfer simulation was coupled into jEPlus (.jep) to perform optimization. A jep project contains the optimization variables which includes a weather file, idf file, and a rvi file. The input data file (idf), is where establishing a wide range of parameters for parametric simulations is created. In this optimization problem, there was a total of twelve effective search space. In the rvi file, EnergyPlus output variables were extracted from EnergyPlus output details document (eplusout.rdd) and output meter variables (eplusout.mdd) files, to input as part of optimization variables in the idf file and objectives defined for simulation in $\mathrm{jEPlus.}$ Subsequently, the jEPlus project was launched for optimization in jEPlus+EA (Zhang, 2015). The optimization was performed, and results were collected for post processing to investigate the optimum specification of parameters for hempcrete simulation. jEPlus+EA was used to simulate the whole solution space. The optimization completed with twelve jobs, in respect of the twelve-search space created in the parameter tree.

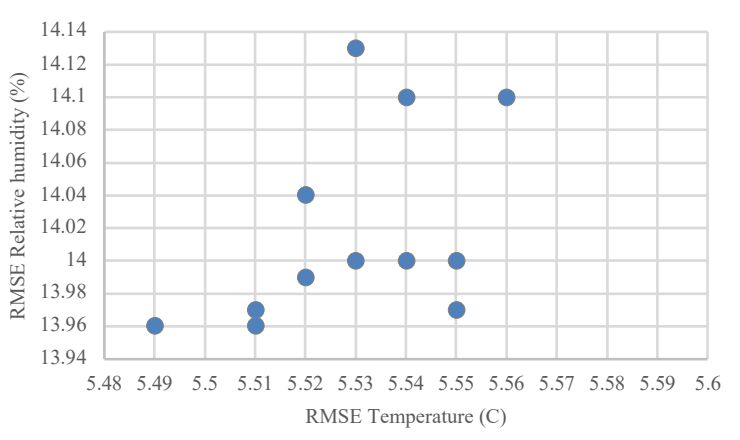

Figure 16:Optimisation of Hemm RMSE values.

Figure 16 above, show the scatter plot with optimization results, the point close to the origin is the optimum solution. With resultant temperature RMSE as $5.49^{\circ} \mathrm{C}$ and resultant relative humidity RMSE as $13.96 \%$.

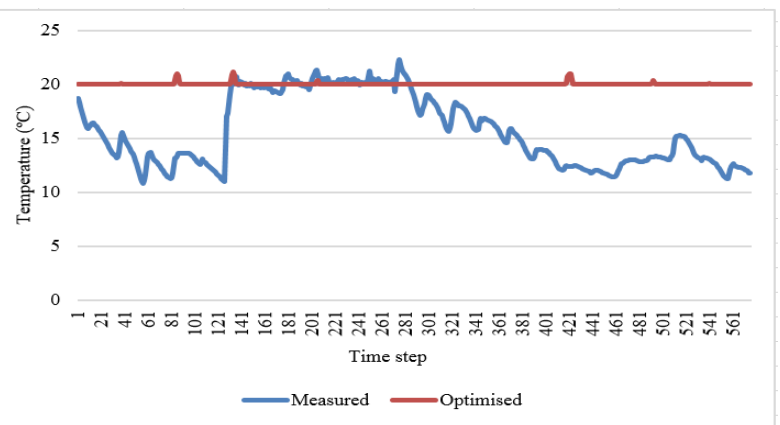

Figure 17:Monitored and Optimised temperature values of Hemm.

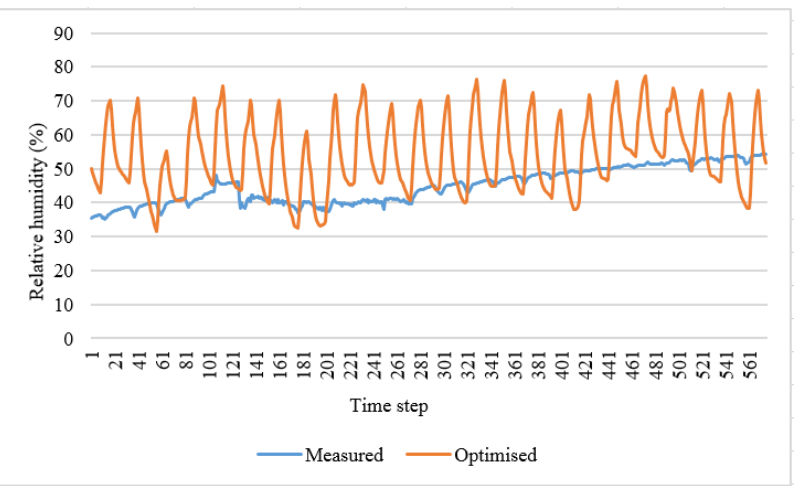

Figure 18:Monitored and optimised Relative humidity values of Hemm. 
From the optimization outputs, the optimum construction for parametric simulation of hempcrete was realised as it seems to maintain a considerable temperature, ranging between $20^{\circ} \mathrm{C}$ to $22^{\circ} \mathrm{C}$ as shown in figure 13 above. And the relative humidity ranging between $32 \%$ to $78 \%$.

\section{Results}

The metric of root mean square error was used to calculate the difference between measured and simulated values of hempod. As seen from the experimental simulation performed in this paper towards reducing simulation performance gap from hempcrete buildings, it is evident that root mean square error was not entirely reduced after multi objective optimization was performed because the original hempod RMSE before experimentation was $5.5^{\circ} \mathrm{C}$ and it was reduced to $5^{\circ} \mathrm{C}$ for $\mathrm{Hemm}$ from the simulation experiments, and the optimisation resultant RMSE value for temperature was $5.49^{\circ} \mathrm{C}$ respectively.

The original hempod value for Relative humidity RMSE was $18.0 \%$, reduced to $15.4 \%$ for Hemm from the simulation experiments; and the resultant optimisation value was further reduced to $13.96 \%$. However, as seen in the optimization performed to minimize root mean square error (RMSE) of temperature and relative humidity from hempod, the potential optimum construction component for hempcrete simulation to achieve stable internal temperature and relative humidity as its actual real-life performance has been realised.

The overall wall construction thickness is $318 \mathrm{~mm}$, containing 12 layers of hempcrete with thickness of $25 \mathrm{~mm}, 9 \mathrm{~mm}$ external rendering and internal gypsum plastering. This hempcrete wall construction was inputted back into EnergyPlus, for parametric simulation after the optimization. This was meant to be a form of validation, and simulations were performed again and figure 19 and 20 below shows the resultant internal temperature as $20^{\circ} \mathrm{C}$ and relative humidity values as $53.4 \%$.

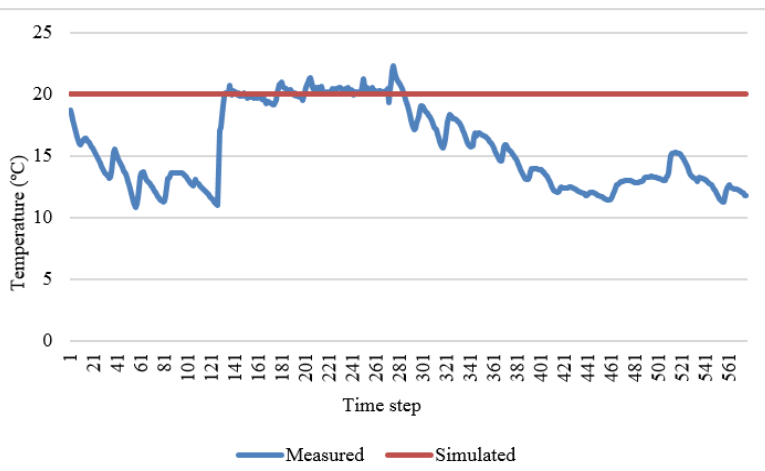

Figure 19:Monitored and simulated temperature values of Hempod.

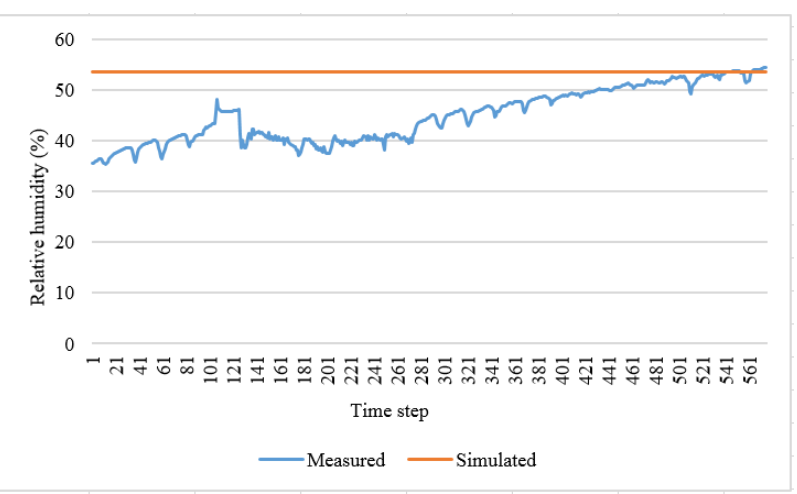

Figure 20:Monitored and simulated Relative humidity values of Hempod.

\section{Discussion}

Some researchers have challenged the ability of designers to estimate building energy performance of a building using simulation and thermal modelling due to uncertainty with the current tools and methods used for building simulation (Ahmad and Culp, 2006; Uusitalo, 2015; Raslan and Davies, 2010). However, building design simulation and building energy simulation technique has immensely aided architects, designers and engineers to achieve energy efficient design of buildings by enabling the users to accurately and rapidly calculate the construction, structural loads and the actual energy consumption of buildings.

Burman et. al. (2012) conducted an experimental study which resulted in demonstrating that, if correct and up to date information is used, dynamic simulation method is very capable of producing realistic results to relate and reflect the actual energy performance of buildings, with a reasonable accuracy. They further highlighted that improving simulation methods is one of the important factors that could help reduce performance gap between simulations and actual performance of a building. This paper extensively investigated how to improve simulation models and simulation method of hempcrete to reduce simulation performance gap. Simulation software's such as IES virtual environment, EnergyPlus program and other software was used to model a hempcrete building and carry out simulations seeking to reduce the simulation performance gap from hempcrete buildings. The results highlight that simulation performance gap was reduced to an extent and that further work is required to eliminate it completely in buildings made from hempcrete.

Unlike the work by Jankovic (2016), who uses post processing of simulation results by Fourier filtering outside of the simulation tools in order to reduce the performance gap, this research aims to create appropriate representation of hempcrete and reduce the performance gap within the simulation tools.

\section{Conclusion}

This paper provides a baseline method towards reducing simulation performance gap from hempcrete buildings, using multi objective optimization. The results were not as expected, which further highlights energy efficiency and high thermal performance of hempcrete in real life 
construction projects. However, the experiments carried out was only in the wall construction and no construction changes were performed on any other part of the hempcrete building for experiments. It is paramount to have different expectations of natural building materials. As seen from the simulations and experiments carried out in this paper, natural materials cannot easily be substituted for conventional materials, this suggests that many of the building techniques currently applied to hempcrete construction methods might not be appropriate to natural buildings such as hempcrete and its simulations. In this paper, the experiments carried out, using layers of hempcrete to form a whole wall is different from the solid thick hempcrete wall of the same thickness, because unlike in conventional brick and block construction, the co-heating test in a hempcrete house exhibited unexpected behaviour; Instead of heating on to a considerable period, it was stopped by a thermostat in half an hour and coincidentally, half an hour later, it started again. This suggests that hempcrete may have a configuration equivalent to a series of slices of high-density material and insulation material. This was the reason for experimenting with slices of hempcrete and a conventional building material as cast concrete. More so, understanding the physics of this hempcrete material is key to further demonstrate that natural materials perform better than conventional materials, in terms of environmental impact, buildability, and thermal performance. At a pragmatic level, a step towards the viability of hempcrete simulation has been proven in this study. And it establishes an opportunity for further research and experiments with hempcrete for totally eliminating the simulation performance gap and increase confidence in designing and simulating with hempcrete. To a reasonable extent, hempcrete provides a solution to the need for more energy efficient forms of construction that are also low carbon, healthy, and breathable. Therefore, reducing or totally eliminating the existing simulation performance gap from hempcrete buildings is essential to the operations of the built environment towards developing resilience to climate change. Also, the results from the experiments conducted in this paper, informs architects, designers and engineers about the material structure and performance gap arising from using this material, and will increase the awareness when designing and building with hempcrete. It highlights opportunities for further improvements in simulations using hempcrete which will be the focus of future work.

\section{References}

Ahmad, M. \& H. Culp, C. (2006). Uncalibrated Building Energy Simulation Modeling Results.Hvac\&r Research. 12 1141-1155. 10.1080/10789669.2006.10391455.

Burman, E., Rigamonti, D., Kimpain, J. and Mumovic, D. (2012). Performance gap and thermal modelling: a comparison of simulation results and actual energy performance for an academy in north west england. In: Building Simulation and Optimization Conference. Loughborough, UK.

Cooke, M. (2018). Analysis of implication and value of The process of calibration of Building Energy Models (BEMs). Energy Technology Partnership.

Deb, K., Pratap, A., Agarwal, S. and Meyarivan, T. (2002). A fast and elitist multiobjective genetic algorithm: NSGA-II. IEEE Transactions on Evolutionary Computation, 6(2), pp.182-197.

Jankovic, L. (2016). 'Reducing simulation performance gap in Hemp-Lime buildings using Fourier filtering', Sustainability, 8(9), p. 864. doi: 10.3390/su8090864.

Monfet, D., Charneux, R., Zmeureanu, R. and Lemire, N. (2009). Calibration of a Building Energy Model Using Measured Data. ASHRAE Transactions 115(1), pp. 348-359.

Raslan, R. and Davies, M. (2010). Results variability In accredited building energy performance compliance demonstration software in the UK: An inter-model comparative study. Journal of Building Performance Simulation. 3. 63-85. 10.1080/19401490903477386.

Sariyildiz, S., Bittermann, M. and Ciftcioglu, Ö. (2015). multi-objective optimization in the construction industry. Delft University of Technology, Faculty of Architecture, Design Informatics, .

Uusitalo, L., Lehikoinen, A., Helle, I. and Myrberg, K. (2015). An overview of methods to evaluate uncertainty of deterministic models in decision support. Environmental Modelling \& Software, 63, pp.24-31.

Zhang, Y., and Jankovic, L. (2017). “JEA, An Interactive Optimisation Engine for Building Energy Performance Simulation." In Proceedings of BS 2017: 15th Conference of the International Building Performance Simulation Association.

Zhang, Y. (2015). jEPlus+EA. Jeplus.org 